\title{
THE FASCINATING FESCUE
}

BERNIE GOLLOP, 2202 York Ave., Saskatoon, SK. S7J 1J1

That wasteland of unruly grasses, patchy brush and scruffy aspen bluffs on the edge of town is not the boring site it might appear from a distance. A closer look will reveal it is a beehive of activity, a fraction of which is described in this article.

This is a weekly account of selected observations on the Central Avenue prairie, located on the east side of Central Avenue north of Garvey St., in the Silverspring neighbourhood of Saskatoon. The Saskatoon Nature Society had its Interpretation Centre on the southwest corner. This article is based on notes made on 135 days between 15 April 1994 and 25 January 1995. This land is not the fenced Grassland Reserve (closed to the public in 1994) which lies between this prairie (where residential development began in 1995) and the Forestry Farm Park. The prairie described here had a $1.5 \mathrm{~km}$ self-guided nature trail which was the general route for each trip.

Some statistics: trips were made on four-six dates per month in April, May and June, and on 15-20 days monthly from July through January. During the butterfly season (15 April18 October) 35 trips were made in the morning, 57 in the afternoon and four in the evening. There were 12 days on which two trips were made and two with three trips. More than three-quarters of the trips were from 1-1.5 hours long. The earliest and latest field work was 8:28 a.m. and 8:14 p.m. CST - both on 5 August. My assistant (whose only credential was enthusiasm) on most trips was a pup named Journey.

In addition to plants mentioned in the weekly accounts, common flowers of the prairie included: Moss Phlox, Early and White Cinquefoils, Silvery Groundsel, Strawberry, Pale Comandra, Wild Flax, Reflexed Rock-cress, Tufted and Rough Daisy Fleabane, Canada Anemone, Yarrow, Northern Bedstraw, Slender Beardtongue, Skeletonweed, Hairy Golden Aster, Purple Prairie-clover, sages, Saskatoon, Hawthorn, Wolfwillow and Choke Cherry. (Flower names are from Wildflowers Across The Prairies by Vance, Jowsey and McLean. 1948.) Among the native grasses were: Plains Rough Fescue, Northern Wheatgrass and Western Porcupine Grass.

This is the sketchiest of summaries. In most cases what is reported for a given week could be repeated several weeks before or after in another year. Usually each plant, bird and butterfly are mentioned only once. Over a three-year period, 130 species of birds and 38 butterflies have been found. On this project the totals were 70 birds and 23 kinds of butterflies. The 1994 butterflies are mentioned in the weekly accounts; other species seen in previous years were: Orange Sulphur; Gray and Bronze Coppers; Western Tailed-, Silvery, Northern, and Greenish Blues; Spring Azure; Silver-bordered Fritillary; a checkerspot; Painted Lady; Eyed Brown; Alberta Arctic; a duskywing, and Common Roadside- 


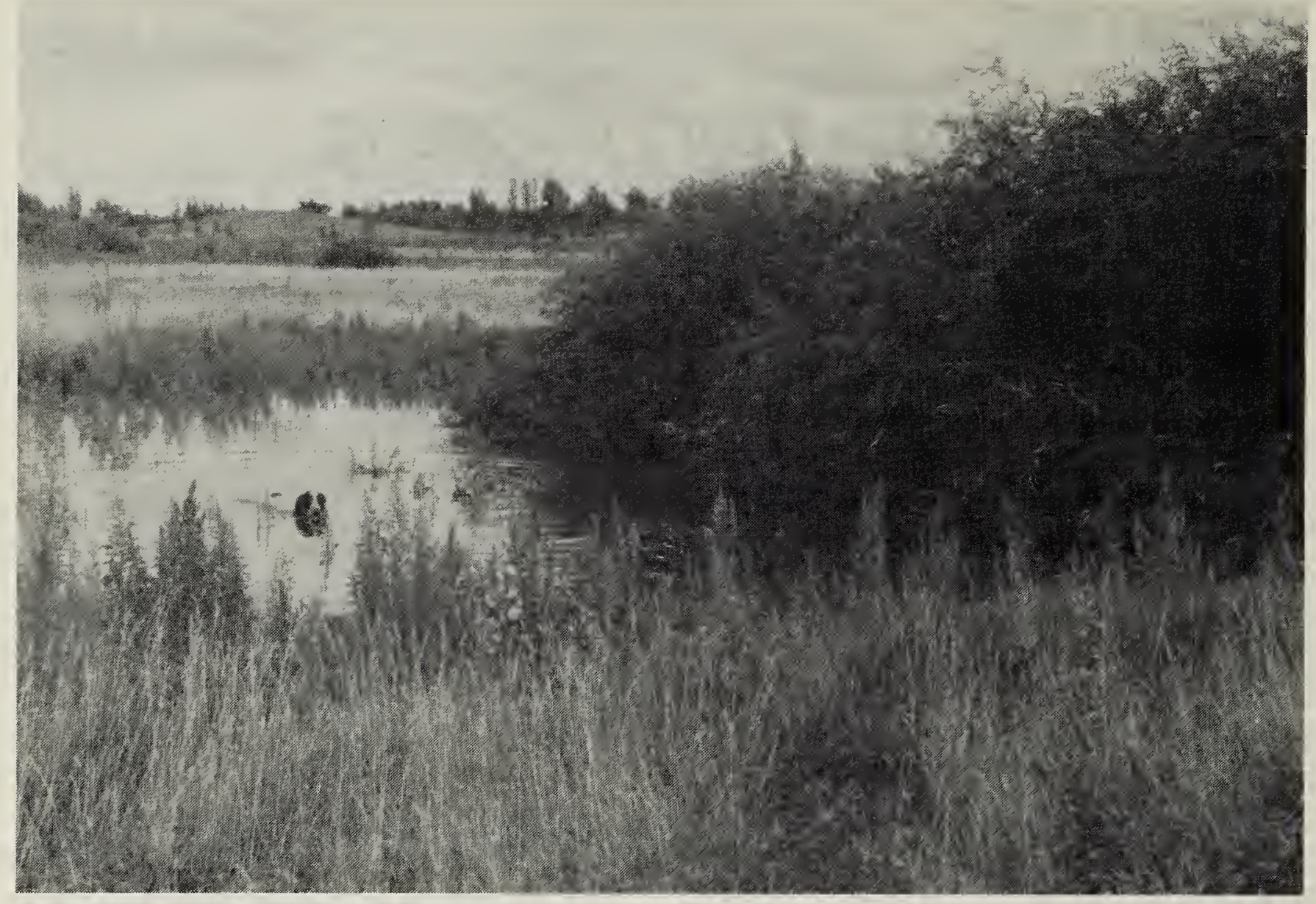

Skipper. (Butterfly names are taken from the Checklist \& English Names of North American Butterflies published by the North American Butterfly Association. 1995.) There were six species of mammals (plus a coyote previously), one snake and a frog.

9-15 April/1 day in the field: Counted 1,457 Prairie Crocuses along the trail on 15 April. ... The only butterfly was some kind of white flying across the prairie. ... Breeding birds included a year-round resident - Black-billed Mapgie - and two early breeding species - four singing Western Meadowlarks and a Killdeer. ... American Crows, white-headed gulls and Canada Geese flew by - apparently on migration. ... A Richardson's Ground Squirrel expressed her opinion of our presence with loud, short, piercing whistles.

16-22 April/3 days: Migrants included Sandhill Cranes overhead while American Tree Sparrows, resting on their way to the Arctic, sang long and melodiously in some willows. ... An American Robin clucked in alarm and a Northern Harrier hunted over the grass. ... There were a few small brown moths, bees, hornets, a beetle and a spider. ... Pussy Willows were out. ... The ground was bare except for several driftlets. ... At least five depressions were holding water in grass, brush and aspen.

30 April-6 May/2 days: Even though temperatures did not get above $10^{\circ} \mathrm{C}$ on the 4th, two individuals of our most common white butterflies Cabbage Whites - were out foraging, as well as a red-tinged, dark brown Red-disked Alpine and a Milbert's Tortoiseshell, the last probably recently emerged from hibernation. (In summer butterflies do not usually fly until the temperature is about $\left.16^{\circ} \mathrm{C}\right)$... Also several minute orange moths. ... Birds feeding on the prairie before going further north included a Swainson's Thrush, White-throated and White-crowned Sparrows. ... 


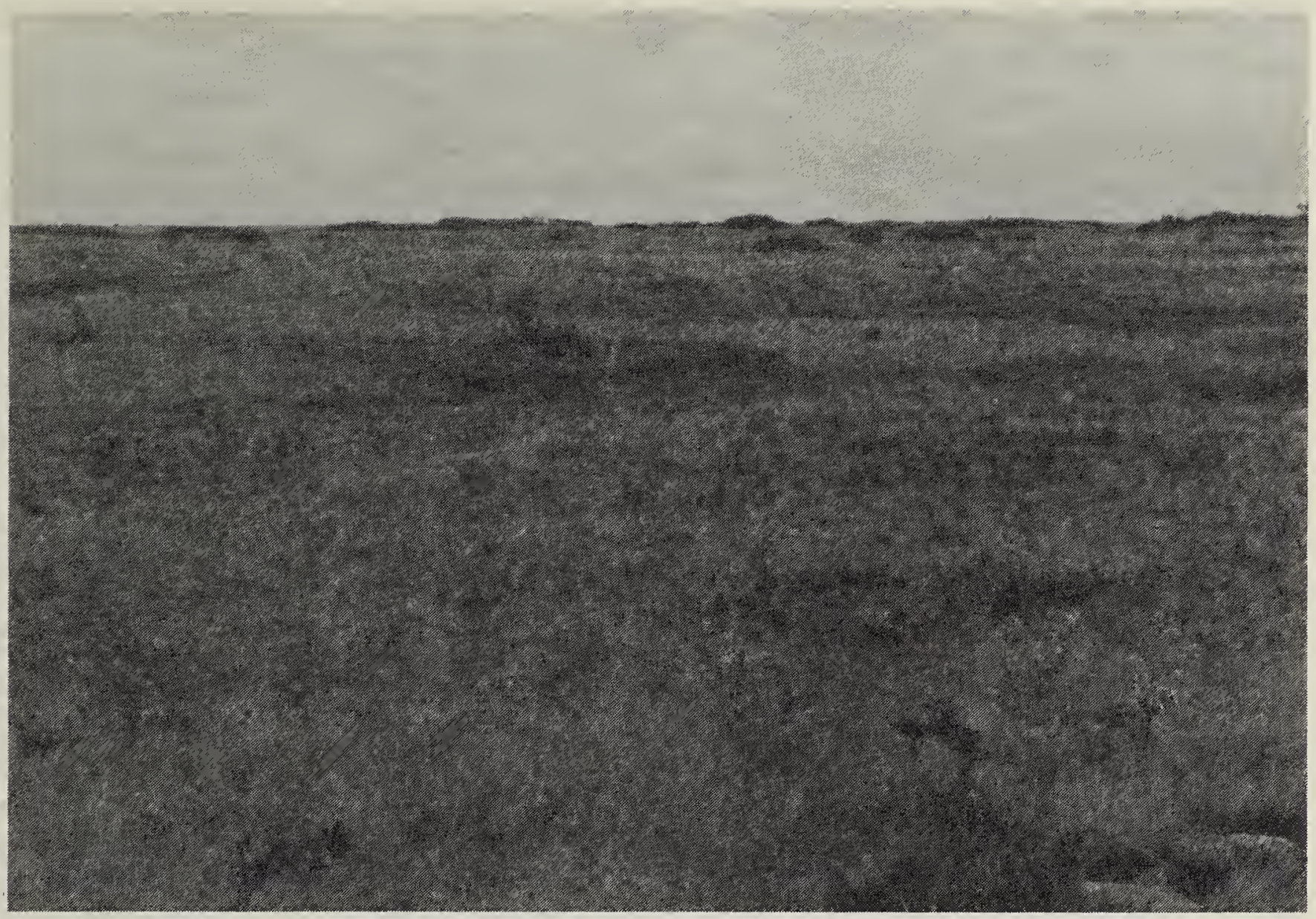

Franklin's Gulls migrated westward. ... Magpies were building a nest.

7-13 May/2: Probably the same alpine, tortoiseshell and white were patrolling their territories. ... Breeding birds that arrived included Claycoloured, Savannah and Vesper Sparrows, robins, Red-winged Blackbirds, Brown-headed Cowbirds, and a Tree Swallow. The swallow was investigating a metal box. ... A crow called from a bluff. ... Colony of Brewer's Blackbirds had commandeered the buckbrush north of the interpretation centre. ... A Thirteenlined Ground Squirrel played hide and seek with us, all the time whistling excited, trebled notes. ... First Three-flowered Avens, Early Blue Violets and a little yellow flower. ... Six Prairie Crocuses still in bloom.

14-20 May/1: Yellow Warblers were singing. ... A pair of Mallards flew in wide circles, low over the prairie, looking for a nesting site near two temporary ponds. ... Golden-bean was the dominant flower.
21-27 May/1: First sulphur butterflies. ... Field Chickweed was common and Early Yellow Locoweed had started to bloom. ... The prairie was becoming more colourful and musical: yellow and black American Goldfinches, an orange and black Northern Oriole, House Wren, Eastern Kingbirds and a Least Flycatcher were proclaiming their territories.

11-17 June/1: Missed 19 days missed the start of the butterfly explosion. ... On 11 June I saw 2 Common Alpines, 11 Clouded Sulphurs, 16 blues (probably more than one species) and 77 Common Ringlets. Ringlets are dull orange butterflies, smaller than whites, that flop around in apparently haphazard directions low over the grass. ... Found a Claycoloured Sparrow nest with two eggs of its own and one cowbird's (which was not there when I left). ... A Purple Vetch was blooming and Cedar Waxwings had arrived.

18-24 June/2: Heard a Brown Thrasher. ... Butterflies included the 


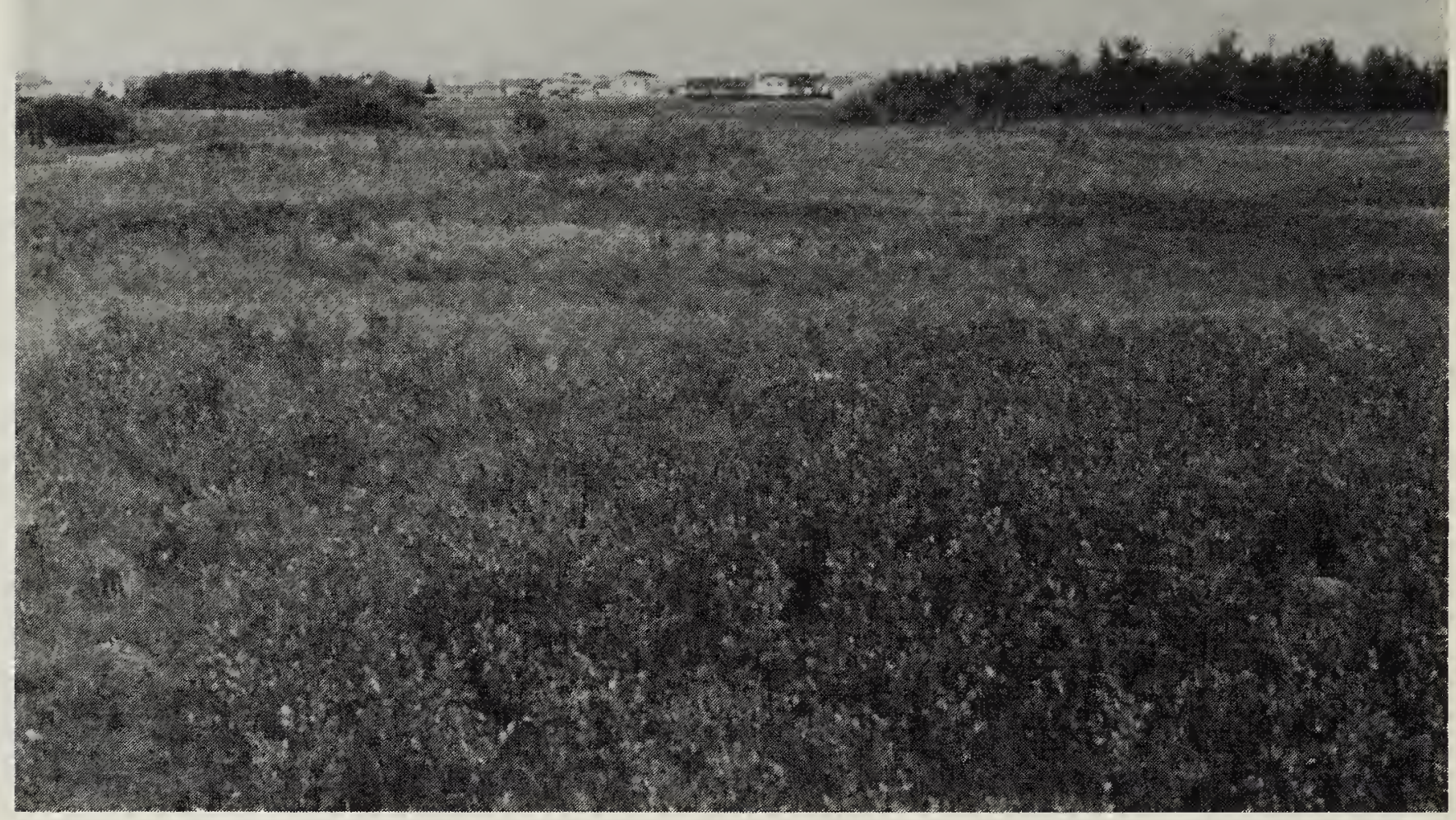

The prairie looking south

Bernie Gollop

season's first Melissa Blue and Uhler's Arctic.

25 June-1 July/2: Ringlet numbers were declining - only 36 on the 28th. ... Saw two brief, ferocious fights today: blue vs. ringlet and skipper vs. ringlet. Both seemed to end in draws ... Most of our skippers are brown and orange butterflies, about a half-inch long, fly rapidly and change directions frequently - making them difficult to find and to follow. Seeing 25 in one day suggested there were many more. At least some were Garita Skipperlings. ... Twenty kinds of birds this week, including Gray Catbird and Mourning Dove.

2-8 July/3: Heard a Rufous-sided Towhee for the first time; more likely a wandering bird than a prairie breeder. ... A Northern Flicker may be nesting. ... Barn and Bank Swallows flying over. ... Spent a trip photographing flowers and a Great Horned Owl feather with a cam- cor- der. ... Was startled by a Whitetailed Deer exploding from the grass.

9-15 July/4: The season's last ringlets and its first Common WoodNymphs. ... Could not catch a crescent. ... Also a Compton Tortoiseshell. ... Heard a Baird's Sparrow. ... Looks like rains have ensured that the small pond near Stop 8 will be the only one to survive the summer.

16-22 July/5: Wood-nymphs jumped to 43. ... A newly hatched Mallard brood skittered into the willows on the Stop 8 slough, which had risen so that it now came across the trail. Blooming meadowsweet occupied about one-third of it. ... A Swainson's Hawk called high above. This bird nested on the prairie before it became so heavily used; probably in the adjacent prairie further north now. ... A stray Pine Siskin flew over as did Purple Martins. ... A Downy Woodpecker worked one of the bluffs. ... Heard a Warbling Vireo. ... Clouded Sulphurs - apparently the 
only yellow butterfly on the prairie were increasing - 24 on the 20th and 49 on the 21st. ... Also the first Great Spangled Fritillaries and a small fritillary. ... A Mourning Cloak rushed westward across the prairie. ... On the 22nd two trips: between 9:00 and 10:00 a.m. I counted 41 sulphurs; between 1:00 and 2:00 p.m. 40. Wood-nymphs may be later risers -14 early and 27 later.

23-29 July/5: Wood-nymphs were the most common butterfly on the prairie -148 in an hour and a half. ... Counted 240 butterflies in one trip. ... A late Prairie Crocus was blooming along the trail. ... Found two albino Dotted Blazingstars on the east side. ... Had a brief look at a rapid garter snake $-30-35 \mathrm{~cm}$ long. ... Also a small Wood Frog. ... Two White-tailed Deer. ... Made an evening trip when sulphurs were going to bed. Counted 25 in 28 minutes prior to 6:50 p.m. but only four in the next 29 minutes. Temperature was still $24^{\circ} \mathrm{C}$ at the end and sunset was about 9:13.

30 July-5 August/5: Butterflies were everywhere. ... Still 147 woodnymphs on the 30th. ... Two Purple Martins harassed a harrier. ... One departing White-tailed Jackrabbit. ... First White Admiral this year on the prairie. ... The white blazingstars were barely recognizable. ... A Mallard hen with eight young on the pond - maybe too young to be the same brood as two weeks ago. ... Saw a Tennessee Warbler, probably a southward migrant. ... First signs of mating: two copulating pairs of wood-nymphs and another of blues. ... Also a Western White - first identified this year. ... Another evening visit: four Cabbage Whites in half an hour before 7:40 and none in the half hour after. ... 21 species of birds this week, including a flock of
24 Canada Geese, a Horned Lark and an American Kestrel - four or five species more than on the average summer day.

6-12 August/3: Fall bird migration had definitely begun: a Solitary Sandpiper on the slough (which had reached a high level for the third time this summer). ... Identified the first Common Branded-Skipper and added Red Admiral and Blackcapped Chickadee to this year's prairie list.

13-19 August/5: Single Aphrodite, Mormon and Variegated Fritillaries identified. Probably among unidentified butterflies seen earlier. ... A wandering Loggerhead Shrike. ... A Red-tailed and a Swainson's Hawk disputed the air space high above. ... Two-thirds of the large Canada thistle patch between Stops 6 and 7 had gone to seed. ... Eleven species of butterflies this week, three or four more than on an average day in July and August.

20-26 August/4: First and only Little Wood-Nymph. This record was a $150 \mathrm{~km}$ northward extension of its range in Saskatchewan. ... Last Common Wood-Nymphs, ending a six-week season for this singlebrooded species (Chart 1). ... The 26th was overcast, rain until start of 56 -minute hike; $12^{\circ} \mathrm{C}$. No butterflies - too dark, too cold, too wet.

\section{August-2 September/5: Two}

Prairie Crocuses in bloom at the edge of the trail. ... Migrants to the prairie were Merlin, Hairy Woodpecker, Common Yellowthroat and three Blue Jays. ... A flock of 80 White-fronted Geese conversed as they headed south from their Arctic breeding grounds. ... A migrant Sora showed up at the pond which had a thin coat of green algae on it. ... 


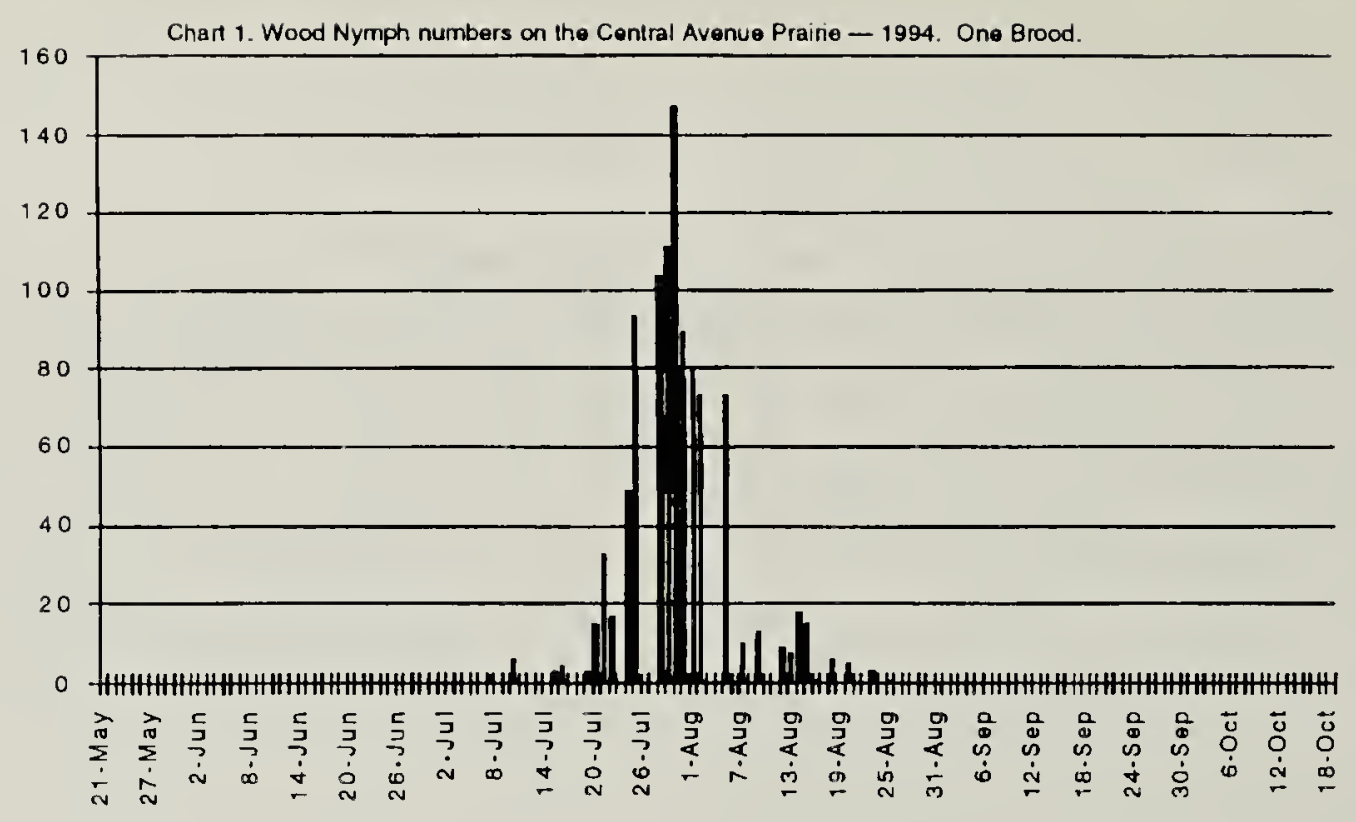

Flock of eight Gray Partridge. ... A garter snake - $12.15 \mathrm{~cm}$ long one day and another $-15-18 \mathrm{~cm}-$ the next. ... Up to 106 whites (probably all Cabbage).

3-9 September/4: On the 5th, many sulphurs were flying south. So I sat on a hillside facing west between Stops $2 \& 3$ to check a $200 \mathrm{~m}$ width of prairie with binoculars. In 40 minutes from 10:32 a.m., 392 sulphurs flew south (nine went north) which works out to almost 600 sulphurs per hour across that narrow band. How wide was the flight, how many hours did it last, how many days might it continue, and why was it made? The highest count walking the trail was 163 this week. ... The next day 91 sulphurs flew south in 30 minutes after 3:16 p.m., the equivalent of $180 / \mathrm{h}$. ... On the 8 th most sulphurs \& whites were headed south all across prairie. ... Two days this week a Common Checkered-Skipper gray-brown with white spots - patrolled the parking lot. ... Found a Clouded Sulphur in a spider web, a foot above ground between two grass stems. Helped it escape on its own. ... Less than $5 \%$ of the Canada Thistle patch is in bloom. ... Saw a Thirteen-lined Ground Squirrel. ... Migrant birds included a Northern
Waterthrush at the pond and two Lincoln's Sparrows.

10-16 September/5: The Sora apparently ended its 13-day vacation on the slough. ... As if waiting for it to leave, four Common Snipe occupied the pond and a fifth flushed from the nearby prairie. ... Other migrants were an Orange-crowned Warbler and a White-crowned Sparrow. ... Found the Checkered Skipper on the parking lot twice this week, once on a common dandelion, instead of the ground. ... Unusual butterflies were Western White and Melissa Blue. ... Counted southbound sulphurs for 10 minutes on the 12th and 13th, getting the equivalent of 115 and 138 butterflies per hour. ... Pond still at twothirds of peak area. ... Among the few flowers in bloom along the trail were: one each of Dotted Blazingstar, Goats-beard, Many-flowered Aster, gaillardia, Flodman's Thistle and Owl's-clover; 5 goldenrods and harebells; 15 dandelions, more Canada Thistles and several hundred sow-thistles.

17-23 September/5: Aromatic smoke noticeable from northern forest fires. ... The Checkered Skipper was found some days, not others. ... Another Mourning Cloak westward across the 
prairie, disappearing beyond binocular range. ... South-bound sulphurs decreased through the week, falling from $144 / \mathrm{hr}$ to $66 / \mathrm{hr}$. ... The five snipe were still feeding at the slough. ... Migrants included Great Blue Heron, Yellow-rumped and Palm Warblers. ... Also three Sandhill Cranes - calling from the clouds and two American Tree Sparrows. It has been five months since these two species were here on their way north. ... About half the leaves were off the trembling aspens.

24-30 September/4: The Checkered Skipper apparently ended his 21 days of parking lot duty. ... Up to three snipe continued to use pond and prairie. ... Southbound sulphurs were petering out: down to 18 /hour. ... Migrant birds continued to drop in - Dark-eyed Juncos, Rusty Blackbirds and a Le Conte's Sparrow. ... A few grasshoppers \& crickets.

1-7 October/5: The trail was made up of about $90 \%$ long, flattened grass, $9 \%$ shorter grasses and mosses, and $1 \%$ rock and bare earth. ... On the 1st, I noted two bumblebees, a honeybee, two flies, two flying beetles, a spider and the season's last dragonfly - small and brown. ... Also a Savannah Sparrow, American Goldfinch and Pine Siskin. ... Saw 10 Clouded Sulphurs on the 5 th as well as a comma and a white. ... Flowers that might provide nectar for them along the trail were scarce: 1 Many-flowered Aster, 1 Harebell, 1 White Sweet-clover, 2 rape, 12+ sow-thistles, 2 Flodman's Thistles, $10 \pm$ nodding-thistles, $10+$ dandelions and some alfalfa were noted. ... Pond was down to a quarter of its greatest area. ... Most leaves off buckbrush (or snowberry) and aspen. ... One large black-\&-whitewinged grasshopper and four smaller ones. ... A flock of $20 \pm$ small midges low over a small bare rock - maybe attracted by its heat.

8-14 October/5: Hovering flock of $40 \pm$ midges over buckbrush. ... Seventeen very tame Rusty Blackbirds feeding as we walked through what was left of the slough. ... Spider strands were blowing in the wind from pond vegetation. ... Seven sulphurs on the 9th; in the last few days most of them have been in the Central Ave. ditch where alfalfa is flowering. ... Also a lady bug, yellow jacket, house-fly type, five small grasshoppers and a bright brown spider, half-inch across, including legs. ... Flushed five Gray Partridge. ... The snipe terminated their stay after 29 days; the last two were at the pond - no surface water - on the 13th. ... Tragedy: next day a pile of about 75 fresh snipe feathers in pond mud; no sign of a struggle; probably an avian predator. ... Practically all leaves were off the aspens. ... A dead shrew on the trail; no sign of blood; body: $40 \pm \mathrm{mm}$; tail: $32 \mathrm{~mm}$. Found one in the same condition 18 September 1993.

15-21 October/3: End of the butterfly season: one sulphur twice or two sulphurs on the 18th (final date in 1993 was the 23rd). Producing two broods, they enhanced the prairie for five months - more abundantly than any other butterfly (Chart 2).... A Pine Grosbeak, arriving for the winter, flew over, giving single, musical notes. ... Walked through the pond bottom. Thousands of small holes all across it, made by snipe as they probed for food. ... Flushed a deer. ... Seven dandelions blooming around parking lot.

22-28 October/4: A swirl of 30-40 midges on the 23rd and another of $25 \pm$ on the 27th. ... The brightest feature on the prairie were red rose 


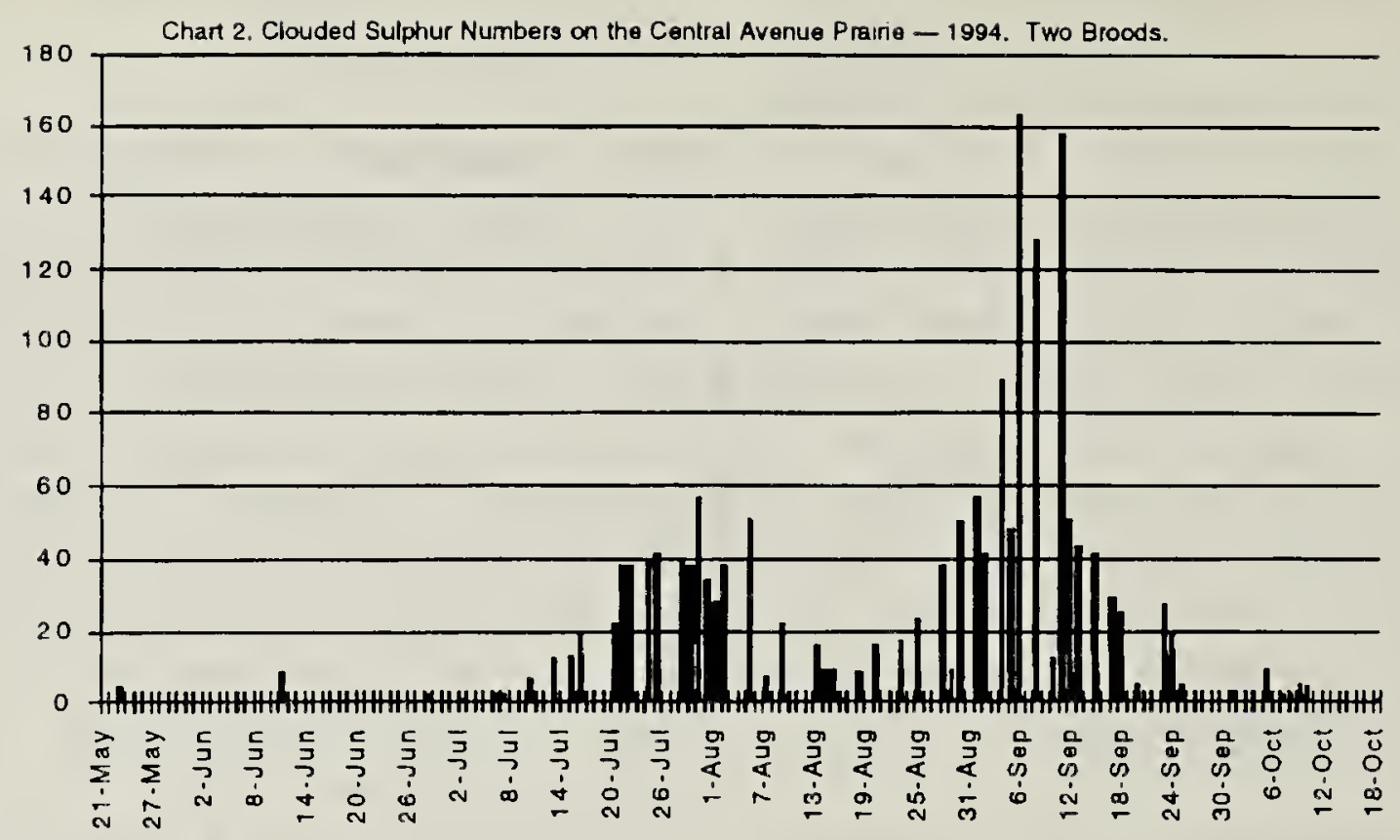

hips; not many. ... A few juncos. ... On the 28 th: $-1{ }^{\circ} \mathrm{C}$; first frost in shade. ... Small white spider; body $2-3 \mathrm{~mm}$. ... A deer.

\section{October-4 November/3: First} snow on the 2 nd $-2.5 \mathrm{~cm}$ on the ground. ... Many rabbit and several deer tracks. ... Mouse trails across the path at 26 places. ... Tops of many rocks bare. ... Nine Gray Partridge. ... A late American Tree Sparrow.

5-30 November/11: Large broken wasp nest in tree. ... On the 10th, $760 \pm$ Canada Geese in the stubble field southwest of the prairie around 3:00 p.m. ... Ground one-third snowcovered on the 10th, $99 \%$ snow-free on the $23 \mathrm{rd}$ but with $5 \mathrm{~cm}$ of snow on the 28th. ... Three White-tailed Deer flying from an aspen grove. ... A siren started coyotes \& wolves howling in the Forestry Farm Zoo.

1-31 December/17: On the 1st, $600 \pm$ Canadas in the same field. The next day flocks of 40 and 150 headed south over town and none were seen in the vicinity after that. ... 9 Decem- ber, first ski tracks on the prairie.... 12th: three Common Ravens flew vociferously over the Forestry Farm. ... On the 15th, a Northern Goshawk scrutinized us disapprovingly from a fence post. ... Long, short and multiple arcs sculptured in the snow by grass tips blowing back and forth. ... Mouse, hare and partridge tracks close enough to fit into one photo frame. ... Hoarfrost heavy on grass and weeds. Pretty in the sun. ... As the snow melted, small, interestingly shaped patches evolved. ... Also translucent ice-bridges reached from one snow islet to another.

1-25 January/15: On the 4th: $-20^{\circ} \mathrm{C}$ with $10 \pm \mathrm{cm}$ of snow on ground. ... Much hoarfrost. ... Journey expended some energy on a jackrabbit twice. ... 10th: $330 \pm$ Bohemian Waxwings in a bluff. ... 13th: A porcupine in the grass and weeds south of the parking lot. Again on the 18th. ... 16th: $10-15 \mathrm{~cm}$ of new snow yesterday and today. ... Eight partridge. ... A quick Red Fox. ... 12th: 1st snowmobile tracks. ... 24th: wolves and coyotes carolling. 